\title{
Creating Demand in Cultural and Leisure Activities by Means of Advertisement
}

\author{
Elena A. Nozdrenko* \\ Siberian Federal University \\ 79 Svobodny, Krasnoyarsk, 660041, Russia
}

Received 23.08.2014, received in revised form 04.10.2014, accepted 27.01.2015

\begin{abstract}
With the development of market economy, cultural and leisure spheres should not only choose, but also forecast promising directions of their development. The mechanisms of this prediction have a complex structure associated with the main line of cultural policy. Since setting the objectives of cultural and leisure activities is related to the organization of leisure for socially important purposes, so the need to carry out skilled work on the formation of the current demand for this type of free time activities is obvious today. The issue of qualified promotion of cultural product today is quite problematic. One of the reasons (and this is a question of marketing) is the lack of demanded cultural product aimed at the satisfaction and development of cultural needs and interests of the individual. The second reason is related to the lack of understanding (and often ignorance) of technologies to effectively promote this type of product, which embodies the specifics of the industry of cultural and leisure activities, which, in turn, demonstrates humanistic, cultural and developmental nature. A critical role in the effective implementation of the idea of forming the actual demand for cultural leisure belongs to different informative and persuasive promotion technologies. Modern advertising is not only a reflection of the society culture, but also the ability to participate significantly in the formation of this culture, including the culture of consumption. Advertisement promotes socialization through broadcasting of images and standards using the mechanisms of mass communication, in which the society applies technological methods of producing social values. The professional approach to promotion of the product of cultural and leisure activities and the approach to its customer as an individual leads to the realization of the need to use new communication technologies (advertising, PR, etc.) They can meet the demands of modern society and also: 1) form the current demand for this type of cultural production; 2) create new needs of the individual, affecting and determining the spiritual and cultural life of society.
\end{abstract}

Keywords: advertisement, culture, social and cultural sphere, cultural and leisure activities, promotion and leisure.

This article was published with the financial support of Federal government budget agency "Russian Foundation for Humanities» (project № 14-13-24002) and "Krasnoyarsk regional fund to support scientific and technical activities» (project № KF-458).

Research area: culture studies.

Development of various forms of mass communication in modern society becomes the most important factor affecting the content and dynamics of social and cultural processes. One of the phenomena of modern culture and a form of mass communication is advertisement.

(C) Siberian Federal University. All rights reserved

* Corresponding author E-mail address: elena.nozdrenko@mail.ru 
Research and analysis of the possibilities of advertisement are carried out primarily in scientific modeling of the very advertising activities, numerous forms and methods of influence on a specific form of social behavior, which is consumer behavior. Empirical and scientific advertising concepts, that have applied nature, find an expression in the professional advertising, media and subjects of social and cultural activities. In our study, we will use our own definition of advertisement as the basic one: "Advertisement is the driving force behind the controversial process of creating, maintaining and changing the basic ideals of culture, when mass communication mechanisms are used to model consumer behavior, in dialectical interaction of self-organization of cultural forms and external factors of cultural development" [Nozdrenko, 2006].

\section{Cultural and leisure activities as one of the fundamental components of proper society functioning}

Given the fact that setting the objectives of cultural and leisure activities is related to the organization of leisure for socially important purposes, it is necessary to carry out professional work on the formation of the current demand for this type of free time activities. Cultural and leisure activities are the process of creating, distributing and multiplication of spiritual values. N.F. Maksiutin offers the following definition: "Cultural and leisure activities are a specialized subsystem of the spiritual and cultural life of society, functionally uniting social institutions to ensure the dissemination of spiritual and cultural values, their active and creative development in the field of leisure activities in order to create a harmoniously developed and creatively active person" [Maksiutin]. Cultural and leisure activities characterize two main features: perception of this activity not only as a profession, but also as an internal need; the exchange is not aimed at the product of activity, but the activity itself through communication and entertainment. Cultural and leisure activities can be considered as a purposeful process of creating the conditions for a reasoned personal choice of the subject activity and also as perceptual-communicative process, determined by the needs and interests of the subject activity, which facilitates the assimilation, preservation, production and distribution of spiritual and material values in the field of entertainment.

Specialists in the field of cultural studies and sociology allocate a number of conditions that can optimize the use of leisure culture creating potential in social and economic conditions of modern Russia. Among them we must firstidentify the humanization of social and cultural activities in spare time, when leisure gets rid of the extrinsic ideological and production functions; updating of national forms of traditional culture and common human values. An important factor is the creation of material, legal, psychological, pedagogical and organizational methods to provide the widespread availability of cultural and leisure activities for all groups of the population, while the state guarantees protection against commercialization of culture and the violation of the principles of social justice, fostering promotion of freedom of creativity and community initiatives in the management of free time of people, as well as supporting the development and implementation of federal, regional and municipal cultural and recreational programs that offer recreation and further spiritual and physical development of the population.

As for the characteristics of culture and leisure activities, they imply that these activities [Strel'tsov]: are done in spare time; are characterized by freedom of choice, voluntary character, energy, etc.; are characterized by a variety of options. 
Cultural and leisure activities become a part of the specific historical program of personal development. Leisure is becoming more and more regulated and controlled type of activity, and is filled with a variety of forms that gradually become interdependent on each other. This allows organizing systematic and purposeful creation of conditions for the formation of the specific historical model of personality and way of life. Cultural activities, via extending through action, cognition and communication of the personal space of the individual, by the means of active transformation contribute to the individual's self-realization and personal development. At the same time people incorporate their experience, creativity, not only acquiring the social experience, but also reproducing it. Cultural and leisure activities are one of the fundamental components of the functioning of society; they have very powerful and meaningful emotional impact on the person. They are a part of the free time, which is spent on meeting social needs, including physical and spiritual, and also appears in the context of the individual's interests related to selfdevelopment, self-realization, communication, pleasure, recreation, meaning the individual's own selection of leisure activities.

With the development of market economy, any cultural and leisure organizations in order to reduce uncertainty and risk must have reliable, objective and timely information that is provided by studies, the competent and professional nature of which will allow: objective assessing of their market opportunities, adaptation to dynamic changes in conditions, selection of the most promising areas of activity. The basis of this research is the analysis of the factors influencing consumer behavior, since the activities of any institution depend primarily on their wills and needs.

\section{Study of factors influencing consumer behavior and shaping demand in the market sphere of cultural and leisure activities}

A systematic approach to the creation, dissemination and multiplication of spiritual values must take into account the differentiated approach to the audience within the framework of cultural policy. This in turn implies a market research (including the study of the real interests and needs of the people), the use of modern technologies to form these needs and motivated choice of the individual forms of cultural and leisure activities, which, apart from the passive presence, also entail the active participation.

The consumer has dual nature. On the one hand, as a member of several social groups everybody is affected by social or external factors. On the other hand, the consumer is individual, and therefore is influenced by a number of internal, psychological factors. Internal, psychological factors are viewed as a process of consumer reaction to external stimuli [Aleshina]. Let us consider these factors in relation to the problems of our study.

EXTERNAL FACTORS. The factors of external influence on consumer behavior consist of: culture, values, demographics, social status, reference groups, households. These factors have, in fact, the varying effect of the groups of various sizes on the consumer. The culture of a country or a nation as the largest social group has the most total and indirect influence on consumer behavior. Culture influences the judgment and behavior of consumers in areas such as self-perception and perception of space (office space, premises, areas of the country or company), communication and language, clothes and appearance, diet, time and its evaluation, the relationships (in family, organization, society), values and norms, beliefs, mental processes, learning style, style of performance and experience [Mazilkina]. It is 
important to note that the marketing activity in social and cultural sphere is not only influenced by culture, but also affects these variables, and to a much greater extent than this very marketing activity does in other areas. Therefore, the establishment of cultural and leisure spheres, on the one hand, in accordance with its social objectives by itself creates new cultural values and promotes traditional ones, on the other hand, the established cultural and leisure spheres use existing cultural attitudes of consumers to promote their services.

The researchers pay attention to the fact that in modern Russian culture there are distinct, numerous and highly contradictory tendencies, connecting the unconnected values and orientations: teamwork, collegiality and individualism, selfishness, deliberate politicization and evident political indifference, statism and anarchy, and so on. On the one hand, there has been a revival of traditional cultural points of reference, on the other hand, there is a strong influence of Western mass culture, and also there is an active penetration of different cultural values and stereotypes. Therefore, the cultural sensitivity of the consumer in marketing of cultural and leisure services is a certain challenge.

Contrariwise, culture is dynamic and adaptive, i.e. at a certain time this or that trend may prevail, and marketing should identify and exploit emerging opportunities. For example, it happens when the country makes significant progress in foreign or domestic policy, or shows a major breakthrough in sports or other activities that increase the population patriotism. In our opinion, in such moments, the consumer pays more attention to the means of promotion, which include a political or patriotic aspect. When promoting cultural activities the use of patriotic slogans and appeals to the civic engagement of consumers and their loyalty to the state are relevant. For instance, the slogan "Support Russian Cinema!" used in advertising campaign of the domestic film, in our view, would work in this situation more effectively.

Despite conflicting cultural reference points in Russia, as the researchers note, traditional social values are still the focal point, and family in particular. So for family leisure club dealing with Russian consumers the slogan "Family - Mum, Dad and me" will be efficient, while in Europe there are cases of administrative sanctions for clothes propagating the same message, which is associated with the promotion of "tolerance" and active lobbying of so called "non-traditional families"[Novikova]. Nearly every modern culture has an interest in other cultures, especially in its unusual, "exotic" forms. With the awareness of this factor one can be successful in influencing consumer behavior of cultural and leisure activities, for example, through the use of the eastern symbolism in advertising, the visual media can make use of images of tropical countries, etc. It is obvious that these means should be relevant to the advertising of a service, and the application of these means depends on its specifics.

When using the cultural factor in promoting leisure activities the institutions of cultural sphere should keep a balance between the goal of attracting the consumer and societal goals, i.e. for the institution of this field it is highly unacceptable to attract consumers by all manner of means. Currently, some institutions of cultural sphere use shoddy stereotypes, shocking antipatriotic methods and other dubious means to promote their services, and they do not contribute to the spiritual development of the consumer. For example, the cinema fliers almost universally use the simplified language, slang, and the descriptions of films are designed for very low levels of education and cultural development. This advertising strategy, of course, attracts 
unsophisticated mass audience, but let us not forget that the cultural and social improvement of the human is always the main task of all cultural and leisure activities.

Following culture the next factor on the scale of influence is subculture and social class. Subcultural differences in the modern world are determined by diverse factors: ethnicity, religious preferences, occupation, region, gender, age, social class differences, etc. (cf. http://www. pattern-cr.ru/). For the purpose of effective promotion via advertising means one cannot neglect the study of subcultures that exist on the market, as their ignorance may cause not only the lack of demand by subcultures' representatives, but also the open confrontation to the product. This rule applies to the sphere of cultural and leisure activities, too. One of the most important for the marketing consultants of cultural and leisure sphere is a youth subculture. In the area of cultural leisure interests and needs of young people are of particular importance as well.

INTERNAL FACTORS. The internal factors of impact on consumer behavior are the processes by which an individual reacts to influence of groups, to changes in surroundings and marketing efforts, including the processes of information perception and learning, as well as personal resources of the consumer [Vlasova].

Perception. Perception involves an individual's past experience in the form of ideas and knowledge. Perception is an intellectual process, connected with the active search for signs, which are considered necessary and sufficient for the formation of an image and decision-making. We shall analyze how the process of perception of advertising and information products, which are designed to promote cultural and leisure activities, evolves. A product "sends" sensory stimuli that are perceived by receptors and influence the human brain, exciting attention, which is the process of conscious or unconscious selection of one piece of information to be received through the senses, and the other part of it to be ignored. To put it simply, the booklet offering the organization of children holiday creates a vivid picture and large text. Then comes the stage of interpretation, or the explanation of received through the senses images based on the preceding or accompanying information. The consumer juxtaposes the image on the advertising leaflet with images the available in the memory and interprets it. At this stage, the image should cause a response by the partial or complete recognition. For example, advertising of children holiday shows the smiling children's faces, which may generate certain associations and a wish to see the consumer's own children in such emotional state. The text is interpreted using the logical analysis based on available resources of language recognition and is then corresponded to the image. As a result, the consumer gets an image of leisure services offered, and if the image is of interest or arouses positive emotional response, the consumer has a desire to get a more detailed view of the proposed leisure activity.

In advertisement of cultural and leisure services the emotional memory is essential, as leisure activity actively involves human emotions. Control of emotional state is made to influence human behavior. The positive emotions about an event create a longing to "appropriate to oneself this event, and the negative emotions lead to the wish to "get rid of the event" [See Emotional Intellect]. Therefore, the consumer better remembers the events that cause positive emotions, including advertising and informational events. For example, the website of the Krasnoyarsk park of flora and fauna "Roev Ruchey" - http://roev. $\mathrm{ru} /$ specially selected photos of animals, causing a variety of positive emotions - affection, pity, admiration to show on the site. Thus, due to the emotional remembering the consumer forms a motive to visit the park in reality. So any person usually better remembers the message which: is 
of interest; more important for the individual; emotionally richer; is not completed in a way and makes the receiver want to complete it (so-called Zeigarnik Effect). These peculiarities of memory must be used in advertising of cultural and leisure services.

Teaching. In a broad sense, teaching is any change in the content or the organization of longterm memory. Therefore it can be concluded that the consumer behavior is mostly of training the behavior. According to I.V. Aleshina, we get most of our attitudes, values, tastes, behavior patterns, preferences, symbolic meanings and feelings through learning. Culture and social class provide a learning experience of consumers through education, family and friends. This learning experience affects the type of life style, which the consumer strives to realize, and the type of products they consume. In the process of marketing communications the consumer's learning takes place too, and consequently the consumer may change their knowledge, skills, attitudes toward goods (services) and, as a final result, the behavior patterns [Aleshina].

Education processes can occur in situations of both high involvement and low involvement of the audience. High involvement in the learning situation happens, when the consumer is motivated to learn the material. For example, an individual who reads the information booklet of the cinema before buying a ticket for a film may be highly motivated to study the material related to cinematographic art. Low involvement in the learning situation happens, when the consumer has little motivation or not motivated at all to learn the material. For example, when the consumer watches a TV programme, which is interrupted by advertisement of the film, this consumer regards films as only one of many possible leisure activities, and in the near future this consumer is hardly likely to visit the cinema, so the user is not motivated enough to respond to the material presented in advertisement. The degree of involvement is set by motivation.

In order to promote many cultural and leisure services one needs to use technology of consumer education. In case the consumer, who has never been to the theater, often can hardly imagine the specific nature of this type of entertainment and does not know what to expect from a visit to the theater. However, the theater is a significant part of culture, and getting consumers attracted to this type of cultural activities has a high social value. Therefore, it is advisable to introduce some elements of education in theater advertising. Unfortunately, in most cases theater advertising is limited to traditional posters. These posters, of course, show various means of attracting attention and interest, but they usually target the consumers with high involvement.

In theater advertising we still hardly ever see examples of consumer education - from elements of teaching at the "beginner level" ("We are having fun together!", "Magic of Theatre", etc.) to more "advanced baits", such as a dictionary of theater terms on the back page of advertising booklet. That means that in this case, first the advertisers highlight some characteristics in the theater as a form of cultural and leisure activities that may be of value in the eyes of the consumer, and then they try to attract the consumers through education. The educational elements are also relevant in the advertising of new types of leisure services, and those services which have traditionally been designed for a narrow range of consumers, but have the potential to win a much wider audience.

In order to ensure high sensitivity of learners there is a need to link new knowledge with their experience. And learning environment should be such that listeners should not hesitate to ask questions and share their experiences with the educated people. This is another argument in favor of interactive marketing of cultural and 
leisure activities. The most effective customer feedback is made in promoting cultural and leisure services through the Internet, by e-mail, instant messaging, comments in blogs and social networks. Among other things, the website of the State Universal Scientific Library of the Krasnoyarsk Territory there are such services as "Bibliography online" and "First aid for bibliographers and local historians", and any library event and activity is regularly covered in the library blog "Day by day, book by book", where there is always an opportunity to get a competent answer to a question by exchanging comments with the authors of informative messages.

Another aspect of education is that if new information on cultural and leisure services cannot match previous experience, it will be understood superficially. Such education is less effective than thoughtful learning, since it is unlikely that it will be fixed in the memory for a long time. We must also identify the following important principles to be followed during the organization of education in the process of promoting cultural and leisure services by means of advertisement. They include:

- admitting the fact that the consumer perceives knowledge or information about cultural and leisure service or facility on the basis of personal preconceptions, and not always in the way the message is presented in the communicative act (for example, in the advertisement). That is why there is a crucial task to get the customer's feedback to determine the actual reaction and compare it with the expected in order to encode the desirable message more precisely.

- admitting the fact that the consumer studies better, when different events are organized to enable them to put in order and integrate new knowledge into their worldview. In modern advertising practice such techniques are very effective, because according to the specifics of information perception, up to $90 \%$ of the message is remembered if the person did something concerning the matter, i.e. was individually involved in the action. In this case, one can judge about the relevance of event-marketing with its contests, quizzes, flash mobs and other promotional activities in the context of cultural and leisure service promotion.

- admitting the fact that the consumer studies better, when the educating content is directly related to their problems or previous background and the educating process is aligned with the accumulated experience. Understanding the target audience is the rule of marketing and advertising, increase in the degree of effectiveness of the teaching during an advertising campaign is possible only if cultural and leisure services are shown attractively and with the usage of the existing social experience for an obvious presentation to the consumer.

- admitting the fact that the consumer studies better, when there is a welcoming atmosphere, providing with opportunities for interpersonal interaction with both teachers and other students, as well as creating conditions, favourable for safe testing of new forms of behavior. In terms of advertising practices and capabilities of information technology, to achieve this condition one should use the virtual presence technologies in social and cultural services. These strategies can be realized on the site of a cultural and leisure centre or via online resource dedicated to specific cultural and leisure services, as well as via social networking and user-friendly blogs, etc. 
- keeping in mind the fact that when learning focuses on problem solving, solutions must come from the consumer, rather than to be "prescribed" by an expert. From the advertisement's standpoint an idea, which provides a solution, always works in terms of impact on the consumer. The objective of advertising communication in this case is to develop competent motivation for a particular audience and, consequently, to achieve the effect of "self-selection" of the consumer of culture and leisure services, when the consumer is inspired by based information and knowledge learned from advertisement.

Personal consumers' resources are their economic status, self-esteem, personal motives and values, lifestyle. Influence of self-esteem is important for the leisure services that involve some competition and initiative of the consumer. These can be a variety of games, quizzes and contests. Such events are more likely to attract the consumers with high self-esteem. Valuable orientations of the consumer also have an influence on the choice of cultural and leisure services. Cultural and leisure services should conform to the system of values of the consumer. For example, a Christian (Orthodox) user is hardly likely to take part in the celebration of Halloween.

It is necessary to take into account the individual style and lifestyle of the consumer to promote culture and leisure services. Lifestyle depends on bringing up, education, surroundings, age. So, the way of life for a large part of the youth is characterized by dynamism, active communication, the increased role of such categories as fashion, "stylish" look and behaviour. Accordingly, this audience chooses such cultural and leisure services, which support these aspects, as well as such services the promotion of which is based on these aspects. For example, the user may either choose to participate in fashionable online game as a result of its compliance with the user's style of life, but may also choose to visit the museum, thanks to the method of promoting the museum service through demonstrating specific to the consumer personal style features and values.

Therefore the behavior of consumers of cultural and leisure services might be affected by a significant number of factors, including the environment, belonging to a particular culture, subculture, group, family and household, social class, as well as the customers' education, age, lifestyle, values and other characteristics. Managing consumer behavior allows, in turn, effective coping with such creating demand factors as price, quality of service, choice of market segment, the effectiveness of communications and advertisement. An important means of demand stimulation is increasing the effectiveness of the work with consumers on the culture and leisure services' market.

\section{Peculiarities of product promotion in cultural and leisure sphere by means of advertisement}

Based on the analysis of the influence of various factors on the behavior of consumers of cultural and leisure services, the research defines the peculiarities of their promotion. The issue of qualified promotion of cultural product today is quite problematic. One of the reasons is the lack of demanded cultural product aimed at the satisfaction and development of cultural needs and interests of both an individual and society as a whole. And to create such product is a task of marketing and advertising in the field of social and cultural activities. The second reason is connected to misunderstanding (and often lack of awareness) of technologies to be used in effective promotion of this type of product, which is associated with the very specifics of the industry 
of cultural and leisure activities, organization of which, in turn, reveal humanistic, cultural and developmental nature.

Advertisement promotes human socialization through setting patterns and norms using the mechanisms of mass communication, with which the society applies technological methods of social values production. Advertisement leads to the creation of social and individual identity, integrates society, advocates a way of social control over the processes, which create ideals, and facilitates cultural changes, being a culture forming, ideals' creating and society integrating factor.

A professional approach to product promotion of cultural and leisure activities and to addressing the consumer as a person, results in admitting the need for communication technologies (advertising, PR, etc.) The promotion should meet the demands of modern society and:

1) generate current demand for this type of cultural production;

2) create new needs of the individual, affecting and fostering spiritual and cultural life of society.

The indicated requirements, in our opinion, are quite feasible, provided an effective appeal to target audiences, taking into account the style of thinking, formed in the modern advertisement culture, which is characterized by the following features [Nozdrenko]:

$\checkmark$ imaginative thinking, which is related to the integration of literature (words) and art (artistic image) in advertisement, contributing to the identification of the objects of the world;

$\checkmark$ associative thinking, which is the connection of the advertised object with encoded inside concepts of dominant in this culture ideals, values, traditions, customs, worldviews; $\checkmark$ eccentricity of thinking, which is associated with resourceful vocabulary used in advertising when the traditional idea about something represents something unexpected;

$\checkmark$ mobility of thinking, which is expressed in short advertisements (slogans), and, as Chekhov's famous saying goes, "brevity is the sister of talent", mobile character of advertisement makes human adaptation to the environment easier;

$\checkmark$ citationality of thinking, which forms the perception of advertising messages as a comparison of several textual worlds. The advertisement cites the situations from the familiar to target audience canonical texts (films, works of art, pieces of music, etc.), quotes the sayings of opinion leaders or geniuses.

While creating the ideals, advertisement performs the function of a specific subject of social communication, without which this process would be reduced to the scholastic declaration only and would be deprived of obvious and actual reality. As a subject of social communication advertisement is a system of institutions operating in the field of socio-economic and socio-cultural processes that ensure interaction of various kinds of social subjects. Whereas the end result of social communication in advertisement is efficiency, manageability, rationalization and social optimization of processes of cultural ideals' formation, the problem of forming new needs of the individual in the field of cultural product consumption is a question of the product's effective promotion.

A. Ul'ianovskii predicts that one of the promising areas of promotional activities in Russia would be "the fostered formation of a symbolic value of and myths about the product" [Ul'ianovskii]. In order to promote the product of cultural and leisure activities the symbolic 
content of advertising images should be rooted in the current social context and a social role of advertising in this case is to provide a consumer with unified and general understanding and interpretation of these symbols in their new conventional realization, which in turn influences the formation of cultural needs, and hence the quality of the consumer's society culture.

\section{References}

1. Aleshina, I.V. Povedenie potrebitelei [Consumer behavior]. M., Ekonomist, 2006. 525 p.

2. Emotsional'nyi intellect: primery programmy formirovaniia [Emotional intelligence: examples of formation programs]. available at: http://magazine.hrm.ru/db/hrm/817861638AA4737B44 25794200494239/print.html (date of reference: 17.04.2014).

3. Koptseva, N.P. (2012). Kul'turologicheskaia baza formirovaniia obshcherossiiskoi natsional'noi identichnosti v Sibirskikh regionakh Rossiskoi Federatsii [Culturological basis of the formation of the all-Russian national identity in the Siberian regions of the Russian Federation]. Vestnik Volgogradskogo gosudarstvennogo universiteta. Seriya 7. Filosofiya, sotsiologiia i sotsial'nye tekhnologii (Bulletin of the Volgograd State University. Series 7. Philosophy, Sociology and Social Technologies), 3, pp. 11-15.

4. Koptseva, N.P., Luzan, V.S. (2012). Modelirovanie kul'tury i kul'turnoi politiki v russkoi filosofii kontsa XIX - pervoi treti XX vv. [Modelling culture and cultural policy in the Russian philosophy from the late $19^{\text {th }}$ century to the first third of the $20^{\text {th }}$ century]. Filosofiia $i$ kul'tura (Philosophy and culture), 4 (52), pp. 105-116.

5. Koptseva, N.P., Luzan, V.S. Gosudarstvennaia kul'turnaia politika v Sibirskom federal'nom okruge: kontseptsii, problem, issledovaniia: monografiia [State cultural policy in the Siberian Federal District: concepts, issues, research: monograph]. Krasnoyarsk, Siberian Federal University, 2012, $383 \mathrm{p}$.

6. Koptseva, N.P., Reznikova, K.V. (2013). Metodologicheskie vozmozhnosti antropologicheskoi shkoly "Kul'tura i lichnost" " dlia sovremennykh kul'turnykh issledovanii [Methodological possibilities of anthropology school "Culture-and-Personality" in contemporary cultural studies]. Sovremennye problem nauki i obrazovaniia (Modern problems of science and education), 4. P. 388.

7. Maksiutin, N.F. Kul'turno-dosugovaia deiatel'nost': konspekt lektsii, opornye zaniatiia i opredeleniia: uchebnoe posobie [Culture and leisure activities: lecture notes, additional lessons and definitions: textbook]. Kazan, 1995. P. 21.

8. Mazilkina, E.I. Povedenie potrebitelei [Consumer behavior]. M., Okei-kniga, 2009. P. 219.

9. Novikova, V. Vo Frantsii zaderzhali muzhchinu za futbolku s izobrazheniem sem'i [A man was arrested in France for having a shirt with a picture of the family], available at: http:/www.spr.ru/ novosti/2013-04/vo-frantsii-zaderzhali-muzhchinu-za-futbolku-s-izobrazheniem-semi.html (date of refernce: 12.04 .2014$)$.

10. Nozdrenko, E.A. Reklama kak factor kul'turno-istoricheskogo protsessa poslednei treti XX nachala XXI vv. [Advertisement as a factor of cultural and historical process of the last third of the $20^{\text {th }}$ century - beginning of the $21^{\text {st }}$ century]. Abstract of Thesis for Candidate of Philosophical Sciences. Novgorod State University named after Yaroslav-the-Wise. Veliky Novgorod, 2006. 
11. Nozdrenko, E.A., Chetvernia O.A. (2012). Rol' reklamy v protsesse formirovaniia tsennostnoorientirovannykh modelei povedeniia detei [The role of advertisement in the process of forming valueoriented behavior of children]. Reklama: teoriia i praktika (Advertisement: theory and practice), 6, pp. 366-377.

12. Nozdrenko, E.A., Koptseva, N.P. Sistema kul'tury: novye determinant. Reklama kak factor kul'turno-istoricheskogo protsessa: monografiia [System of culture: new determinants. Advertisement as a factor of cultural and historical process: monograph]. Krasnoyarsk: Siberian Federal University, 2011. $156 \mathrm{p}$.

13. Povedenie potrbitelei: elektronnyi uchebnik [Consumer behavior: electronic textbook], available at: http://www.pattern-cr.ru/ (date of reference: 12.04.2014).

14. Strel'tsov, Iu.A. Obshchenie v sfere svobodnogo vremeni [Communication during free time activities]. M., Moscow State Institute of Culture, 2001. 352 p. P.103.

15. Ul'ianovskii, A.V. Korporativnyi imidg: tekhnologii formirovaniia dlia maksimal'nogo rosta biznesa [Corporate image: formation technology for maximum business growth]. M.: EKSMO, 2008.

16. Vlasova, M.L. Sotsiologicheskie metody v marketingovykh issledovaniiakh: uchebnoe posobie dlia vuzov [Sociological methods in marketing research: textbook for universities]. M.: Publishing House of HSE, 2006. $710 \mathrm{p}$.

17. White, L. Simvol: proiskhozhdenie i osnova chelovecheskogo povedeniia [Symbol: the origin and basis of human behavior]. Raboty L. Uaita po kul'turologii (sbornik perevodov) (White, L. Works on Cultural Studies (collection of translations)). M.: Institute of Scientific Information on Social Sciences RAS, 1996. 445 p.

\title{
Формирование спроса
}

\section{в сфере культурно-досуговой деятельности средствами рекламы}

\author{
Е.А. Ноздренко \\ Сибирский федеральный университет \\ Россия, 660041, Красноярск, пр. Свободный, 79
}

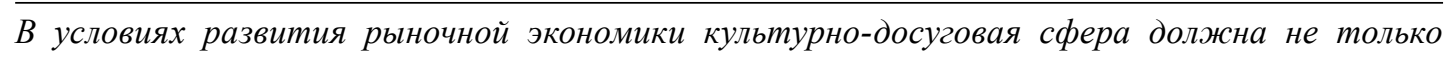
выбирать, но и сама прогнозировать перспективные направления своего развития. Механизмы такого прогнозирования имеют сложную структуру, связанную с магистральной линией культурной политики. Так как целеполагание культурно-досуговой деятельности связано с организацией досуга в социально значимых иелях, то и необходимость осуществлять квалифицированную работу по формированию актуального спроса на данный вид свободного времени очевидна. Вопрос квалифицированного продвижения культурного продукта на сегодняшний день является достаточно проблемным. Одна из причин (и это вопрос маркетинга) - отсутствие востребованного культурного продукта, направленного на удовлетворение $и$ развитие культурных потребностей $и$ интересов личности. Вторая причина связана с непониманием (чаще незнанием) технологий эффективного продвижения данного вида продукта, который обусловлен спецификой самой отрасли культурно-досуговой 
деятельности, организация досуга в рамках которой, в свою очередь, носит гуманистический, культурологический и развивающий характер.

Важнейшую роль в эффективной реализации идеи формирования актуального спроса на культурный досуг занимают различные информативно-убеждающие технологии продвижения. Современная реклама является не только отражением культуры общества, но и сама способна значительно участвовать в формировании этой культуры, в том числе культуры потребления. Реклама способствует сочиализации человека посредством трансляиии образцов и норм через механизмы массовой коммуникации, в рамках которых общество реализует технологические способы производства социальных значений. Профессиональный подход к продвижению продукта культурно-досуговой деятельности и его потребителю как личности приводит к осознанию необходимости применения новых коммуникативных технологий (реклама, $P R$ и др.), способных отвечать требованиям современного общества и: 1) формировать актуальный спрос на данный вид духовного производства; 2) создавать новые потребности личности, качественно влияя и определяя духовную и культурную жизнь общества.

Ключевые слова: реклама, культура, сочиально-культурная сфера, культурно-досуговая деятельность, продвижение, досуг.

Статья опубликована при финансовой поддержке ФБГУ «Российский гуманитарный научный фонд» (№ проекта 14-13-24002) и КГАУ «Красноярский краевой фонд поддержки научной и научно-технической деятельности» (№ проекта КФ-458).

Научная специальность: 24.00.00 - культурология. 